\title{
Net energy and ractopamine levels for barrows weighing 70 to $100 \mathrm{~kg}$
}

\author{
Níveis de energia líquida e ractopamina para suínos machos castrados dos 70 aos $100 \mathrm{~kg}$
}

\author{
Liliane Maria Piano Gonçalves ${ }^{\mathrm{I}}$ Charles Kiefer $^{\mathrm{I}}$ Karina Márcia Ribeiro de Souza ${ }^{\mathrm{I}}$ \\ Danilo Alves Marçal ${ }^{\mathrm{I}}$ Rodrigo Caetano de Abreu ${ }^{\mathrm{I}}$ Viviane Maria Oliveira dos Santos Nieto ${ }^{\mathrm{I}}$ \\ Gabriela Puhl Rodrigues ${ }^{I}$ Stephan Alexander da Silva Alencar ${ }^{I}$
}

\section{ABSTRACT}

The purpose of this study was to evaluate net energy and dietary ractopamine levels for barrows weighing 70 to $100 \mathrm{~kg}$. The 150 pigs investigated (initial weight $70.80 \pm 3.84 \mathrm{~kg}$ ) were distributed in a randomized block design with a $5 \times 3$ factorial arrangement, comprising five levels of net energy (2,300; 2,425; 2,550; 2,675; and 2,800Kcal $\mathrm{kg}^{-1}$ of diet) and three levels of ractopamine $\left(5,10\right.$, and $20 \mathrm{ppm} \mathrm{kg}^{-1}$ of diet $)$, with five replicates, and two animals per experimental unit. No interaction $(P>0.05)$ was observed between net energy and ractopamine levels. Increasing the dietary net energy levels led to a linear reduction in feed intake, with a linear improvement in feed conversion. Net energy levels had no observable effect $(P>0.05)$ on weight gain, final weight, or carcass characteristics. A dietary net energy level of 2,800Kcal $\mathrm{kg}^{-1}$ can be recommended for pigs weighing $70-100 \mathrm{~kg}$, improving feed conversion without affecting carcass characteristics, regardless of dietary ractopamine levels. Ractopamine levels above 5ppm did not affect performance or modify the quantitative characteristics of carcasses, regardless of dietary net energy levels.

Key words: carcass, energy requirement, nutrition.

\section{RESUMO}

Conduziu-se este estudo com o objetivo de avaliar niveis de energia líquida e ractopamina na dieta de suinos machos castrados em terminação dos 70 aos $100 \mathrm{~kg}$. Foram utilizados

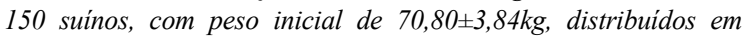
delineamento de blocos ao acaso, em esquema fatorial 5x3, com cinco níveis de energia líquida (2.300, 2.425, 2.550, 2.675

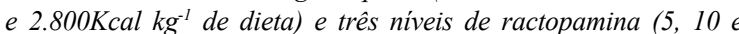
$20 \mathrm{ppm} \mathrm{kg}^{-1}$ de dieta), cinco repetições e dois animais por unidade experimental. Não houve interação $(P>0,05)$ entre os niveis de energia líquida e ractopamina. $O$ aumento dos niveis de energia líquida das dietas proporcionou redução linear do consumo de ração e resultou em melhora linear da conversão alimentar. Não houve efeito $(P>0,05)$ dos níveis de energia líquida no ganho de peso, peso final e nas características de carcaça. Recomenda-se o nivel de $2.800 \mathrm{Kcal} \mathrm{de} \mathrm{LL} \mathrm{kg}^{-1}$ de dieta para suinos de 70 a $100 \mathrm{~kg}$ por melhorar a conversão alimentar, sem prejudicar as características de carcaça, independentemente do nível de ractopamina das dietas. A inclusão de ractopamina na dieta de suínos dos 70 aos $100 \mathrm{~kg}$ não afeta o desempenho e não modifica as características quantitativas das carcaças, independente do nível de energia líquida das dietas.

Palavras-chave: carcaça, exigência energética, nutrição.

\section{INTRODUCTION}

Full expression of the potential of swine of high genetic standard requires diets that meet the animal nutritional requirements. One approach to achieve maximum feed efficiency and carcass quality is the addition of ractopamine to the diets of finishing pigs.

Ractopamine has been shown to improve performance and carcass characteristics (CORASSA et al., 2009) without affecting meat quality (ALMEIDA et al., 2010), while increasing daily weight gain, improving feed conversion, and reducing back-fat thickness, and increasing ribeye area, meat percentage, and carcass meat-to-fat ratios.

In swine, lysine concentrations in deposited protein are higher when diets are supplemented with ractopamine. However, the lysine-to-energy ratios and energy levels required for optimizing performance and carcass characteristics are higher than those recommended in the literature addressing dietary ractopamine (APPLE et al., 2004).

\footnotetext{
'Programa de Pós-graduação em Ciência Animal, Universidade Federal de Mato Grosso do Sul (UFMS), 97070-900, Campo Grande, MS, Brasil. E-mail: charles.kiefer@ufms.br. "Corresponding author.
} 
Reassessing the energy levels of diets supplemented with ractopamine is critical, since constraints to ractopamine activity may limit full expression of productive potential in swine.

The purpose of this study was to evaluate the effect of net energy and ractopamine levels, as well as their interaction, on the performance and carcass characteristics of finishing barrows weighing 70 to $100 \mathrm{~kg}$.

\section{MATERIALS AND METHODS}

One hundred and fifty barrows of a commercial line exhibiting high potential for protein deposition were used in this study. Mean initial weight was $70.80 \pm 3.84 \mathrm{~kg}$. Animals were distributed in a randomized block design with a $5 \times 3$ factorial arrangement, comprising five levels of net energy $\left(2,300 ; 2,425 ; 2,550 ; 2,675\right.$; and $2,800 \mathrm{Kcal} \mathrm{kg}^{-1}$ of diet) and three levels of ractopamine $(5,10$, and $20 \mathrm{ppm} \mathrm{kg}^{-1}$ of diet), with five replicates, and two animals per experimental unit. Blocks were based on initial weight. The animals were housed in pens equipped with semi-automatic feeders and bite nipple drinkers, located in a masonry shed roofed with ceramic tiles.

The experimental diets (Table 1), prepared with soybean meal and corn, were supplemented with amino acids, minerals, and vitamins to meet the nutritional requirements proposed by ROSTAGNO et al. (2011) for barrows of high genetic potential and superior performance weighing 70 to $100 \mathrm{~kg}$. Dietary net energy was calculated based on the mean composition of raw materials (ROSTAGNO et al., 2011). Different energy levels were obtained by replacing kaolin with soybean oil while maintaining an optimal protein pattern across diets. Feed and water were provided ad libitum throughout the 30day experimental period.

Animals were weighed at the beginning and end of the experiment. Weights of supplied feed, leftovers, and wastage were employed to calculate lysine and daily net energy intakes, as well as, daily weight gain and feed conversion for each experimental unit.

Following the final weighing, animals were transported to a commercial abattoir where they remained in stall rest with access to water, but without solid food, for $10 \mathrm{~h}$. For slaughter, the animals were subjected to electronarcosis and subsequently bled, scalded, and eviscerated.

At the end of the slaughter line, the heads were removed, carcasses halved lengthwise, and half-carcasses weighed individually. Left halfcarcass was cut at P2 (the point corresponding to the orthogonal projection of the last rib $4 \mathrm{~cm}$ from the spine) to expose the Longissimus dorsi and back-fat layer for measurements of muscle depth and backfat thickness using digital calipers, before carcass temperature reduced.

Calculations of meat percentage and lean meat amount were based on hot carcass weight, back-fat thickness, and muscle depth using the equations proposed by BRIDI \& SILVA (2007): lean meat percentage $(\%)=60$ - (back-fat thickness $\times 0.58)+($ muscle depth $\times 0.1)$; lean meat amount $(\mathrm{kg})=$ (hot carcass weight $\times$ lean meat percentage) $/ 100$.

Performance variables (weight gain, feed, energy intake, and feed conversion) and quantitative carcass traits (hot carcass weight, back-fat thickness, muscle depth, and carcass meat percentage) were subjected to analysis of variance (general linear model), using SAS software version 9.0. A 5\% significance level was adopted. Initial weight was used as a covariate in the statistical model. Models of best fit were applied using linear and/or quadratic regressions to net energy and ractopamine levels.

\section{RESULTS AND DISCUSSION}

No effect of interaction $(\mathrm{P}>0.05)$ between net energy and ractopamine levels (Table 2) was observed on performance variables, corroborating the results obtained by MOURA et al. (2011a), who reported no effect of interaction between net energy $\left(2,300 ; 2,424 ; 2,548\right.$; and $\left.2,668 \mathrm{Kcal} \mathrm{kg}^{-1}\right)$ and ractopamine levels ( 0 and $20 \mathrm{ppm})$ on the performance of finishing gilts subjected to high ambient temperatures.

No influence of net energy levels of the experimental diets was observed on final body weight $(\mathrm{P}>0.05)$, but feed intake decreased linearly $(\mathrm{P}<0.01)$ with increasing energy levels, a result explained by the fact that pigs can modify feed intake to adjust to dietary energy levels (REZENDE et al., 2006) the higher the dietary energy, the lower the voluntary feed intake. Therefore, finishing pigs provided diets with high energy densities, reduced voluntary consumption, and such diets have been associated with improved feed efficiency. The result corroborated the findings reported by KIL et al. (2011) for net energy levels of 2,056; 2,206; and 2,318Kcal $\mathrm{kg}^{-1}$ and by QUINIOU \& NOBLET (2012) for 3,100; 3,230; 3,370; and 3,500 $\mathrm{Kcal} \mathrm{kg}^{-1}$. 
Table 1 - Composition of experimental diets.

\begin{tabular}{|c|c|c|c|c|c|}
\hline Ingredients & 2,300 & 2,425 & 2,550 & 2,675 & 2,800 \\
\hline Corn & 70.15 & 70.15 & 70.15 & 70.15 & 70.15 \\
\hline Soybean meal (45\%) & 20.44 & 20.44 & 20.44 & 20.44 & 20.44 \\
\hline Soybean oil & 0.000 & 1.697 & 3.394 & 5.091 & 6.800 \\
\hline Inert matter (kaolin) & 6.800 & 5.103 & 3.406 & 1.709 & 0.000 \\
\hline Dicalcium phosphate & 0.832 & 0.832 & 0.832 & 0.832 & 0.832 \\
\hline Calcitic limestone & 0.445 & 0.445 & 0.445 & 0.445 & 0.445 \\
\hline Vitamin and mineral supplement ${ }^{1}$ & 0.100 & 0.100 & 0.100 & 0.100 & 0.100 \\
\hline Salt & 0.305 & 0.305 & 0.305 & 0.305 & 0.305 \\
\hline L-lysine $\mathrm{HCl}$ & 0.451 & 0.451 & 0.451 & 0.451 & 0.451 \\
\hline DL-methionine & 0.159 & 0.159 & 0.159 & 0.159 & 0.159 \\
\hline L-threonine & 0.177 & 0.177 & 0.177 & 0.177 & 0.177 \\
\hline L-tryptophan & 0.037 & 0.037 & 0.037 & 0.037 & 0.037 \\
\hline Ractopamine or inert matter ${ }^{2}$ & 0.100 & 0.100 & 0.100 & 0.100 & 0.100 \\
\hline Net energy (Kcal kg $\left.{ }^{-1}\right)$ & 2,300 & $\begin{array}{l}\text { nutritic } \\
2,425\end{array}$ & 2,550 & 2,675 & 2,800 \\
\hline Metabolizable energy (Kcal kg $\left.{ }^{-1}\right)$ & 3,045 & 3,186 & 3,327 & 3,468 & 3,608 \\
\hline Gross protein $(\%)$ & 16.00 & 16.00 & 16.00 & 16.00 & 16.00 \\
\hline Digestible lysine (\%) & 1.000 & 1.000 & 1.000 & 1.000 & 1.000 \\
\hline Digestible methionine + cystine $(\%)$ & 0.617 & 0.617 & 0.617 & 0.617 & 0.617 \\
\hline Digestible threonine (\%) & 0.667 & 0.667 & 0.667 & 0.667 & 0.667 \\
\hline Digestible tryptophan (\%) & 0.187 & 0.187 & 0.187 & 0.187 & 0.187 \\
\hline Calcium (\%) & 0.484 & 0.484 & 0.484 & 0.484 & 0.484 \\
\hline Available phosphorus (\%) & 0.248 & 0.248 & 0.248 & 0.248 & 0.248 \\
\hline Sodium $(\%)$ & 0.160 & 0.160 & 0.160 & 0.160 & 0.160 \\
\hline
\end{tabular}

${ }^{1}$ Content per kilogram of diet: vit. A, $1250000 \mathrm{IU}$; vit. $\mathrm{D}_{3}, 250000 \mathrm{IU}$; vit. E, 6250IU; vit. $\mathrm{K}_{3}, 750 \mathrm{mg}$; vit. $\mathrm{B}_{1}, 375 \mathrm{mg}$; vit. $\mathrm{B}_{2}$, $1000 \mathrm{mg}$; vit. $\mathrm{B}_{6}, 375 \mathrm{mg}$; vit. $\mathrm{B}_{12}, 4500 \mu \mathrm{g}$; niacin, $4500 \mathrm{mg}$; pantothenic acid, 2300mg; folic acid, $125 \mathrm{mg}$; iron, 25g; copper, 3750mg; manganese, $12.5 \mathrm{~g}$; zinc, $31.25 \mathrm{~g}$; iodine, $250 \mathrm{mg}$; selenium, $75 \mathrm{mg}$; excipient q.s.p. $1000 \mathrm{~g} .{ }^{2}$ Ractopamine hydrochloride instead of kaolin.

No effect $(\mathrm{P}>0.05)$ of net energy levels on daily weight gain was observed. This response is possibly associated with the linear reduction in feed intake with increasing dietary energy levels. Similar results were reported by APPLE et al. (2004) for barrows and gilts and by MOURA et al. (2011a) for finishing gilts.

Feed conversion improved linearly $(\mathrm{P}<0.01)$ with increasing net energy levels. This result can be explained by the positive effects on nutrient digestibility of the oil used as an energy source, as well as by possible improvement in dietary energy-to-protein ratios. Similar results were obtained by PAIANO et al. (2008), who observed that feed conversion improved in finishing barrows and gilts fed diets with increasing net energy concentrations $(2,410 ; 2,450 ; 2,490 ; 2,530$; and $2,570 \mathrm{Kcal} \mathrm{kg}^{-1}$ ), and by YI et al. (2010) who investigated the effects of net energy levels $(2,250$; 2,$300 ; 2,400$; and $2,450 \mathrm{Kcal} \mathrm{kg}^{-1}$ ) in diets fed to pigs with $20-30 \mathrm{~kg}$ live weight.
Moreover, ractopamine levels in the experimental diets did not affect performance variables $(P>0.05)$. This absence of effect may be related to the range of body weights $(70-100 \mathrm{~kg})$ in the experimental period, as prior research has demonstrated the benefits of ractopamine addition to the diets of pigs weighing over $100 \mathrm{~kg}$ at slaughter time, particularly in terms of weight gain (CORASSA et al., 2009) and feed conversion (ALMEIDA et al., 2010). Genotypic features may be another reason why ractopamine did not affect performance, since variability in the genetic materials employed in different studies may affect the variables evaluated (HINSON et al., 2011).

No effect of interaction $(\mathrm{P}>0.05)$ between net energy and ractopamine levels was observed on carcass characteristics (Table 3 ). In addition, no effect of net energy levels $(\mathrm{P}>0.05)$ was observed on the quantitative characteristics of carcasses. These results suggested that the experimental diets 
Table 2 - Performance of finishing barrows fed diets supplemented with ractopamine.

\begin{tabular}{|c|c|c|c|c|c|c|c|c|c|c|c|}
\hline \multirow{2}{*}{ Var } & \multirow{2}{*}{$\operatorname{Rac}(p p m)$} & \multicolumn{5}{|c|}{ 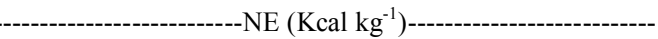 } & \multirow{2}{*}{ Mean } & \multicolumn{3}{|c|}{-P-value- } & \multirow{2}{*}{$\mathrm{CV}(\%)$} \\
\hline & & 2.300 & 2.425 & 2.550 & 2.675 & 2.800 & & $\mathrm{NE}$ & Rac & Int. & \\
\hline \multirow{4}{*}{ FW (kg) } & 5 & 95.42 & 94.46 & 94.68 & 95.25 & 95.61 & 95.10 & & & & \\
\hline & 10 & 99.73 & 98.90 & 98.43 & 97.86 & 96.87 & 98.36 & & & & \\
\hline & 20 & 96.28 & 99.54 & 94.84 & 96.89 & 95.25 & 96.56 & \multirow{3}{*}{0.830} & \multirow[b]{2}{*}{0.206} & \multirow[b]{2}{*}{0.926} & \multirow[b]{2}{*}{4.73} \\
\hline & Mean & 97.14 & 97.63 & 96.07 & 96.67 & 95.91 & - & & & & \\
\hline \multirow{4}{*}{ DFI (kg) } & 5 & 2.34 & 2.27 & 2.21 & 2.09 & 2.06 & 2.19 & & & \multirow[b]{4}{*}{0.878} & \multirow[b]{4}{*}{13.72} \\
\hline & 10 & 2.46 & 2.30 & 2.34 & 2.33 & 1.98 & 2.28 & \multirow[b]{3}{*}{$0.013 *$} & \multirow[b]{3}{*}{0.558} & & \\
\hline & 20 & 2.36 & 2.45 & 2.11 & 2.14 & 1.99 & 2.21 & & & & \\
\hline & Mean & 2.38 & 2.34 & 2.22 & 2.19 & 2.01 & - & & & & \\
\hline \multirow{4}{*}{ NEI (kcal) } & 5 & 5376 & 5519 & 5616 & 5598 & 5777 & 5576 & \multirow[b]{4}{*}{0.780} & \multirow[b]{4}{*}{0.565} & \multirow[b]{4}{*}{0.873} & \multirow[b]{4}{*}{13.86} \\
\hline & 10 & 5653 & 5564 & 5976 & 6245 & 5537 & 5795 & & & & \\
\hline & 20 & 5417 & 5937 & 5373 & 5729 & 5558 & 5603 & & & & \\
\hline & Mean & 5482 & 5673 & 5658 & 5857 & 5624 & - & & & & \\
\hline \multirow{4}{*}{ DWG (kg) } & 5 & 0.81 & 0.8 & 0.79 & 0.84 & 0.83 & 0.82 & \multirow[b]{4}{*}{0.843} & \multirow[b]{4}{*}{0.125} & \multirow[b]{4}{*}{0.945} & \multirow[b]{4}{*}{17.67} \\
\hline & 10 & 0.93 & 0.92 & 0.9 & 0.89 & 0.86 & 0.90 & & & & \\
\hline & 20 & 0.86 & 0.97 & 0.81 & 0.88 & 0.83 & 0.87 & & & & \\
\hline & Mean & 0.87 & 0.89 & 0.84 & 0.87 & 0.84 & - & & & & \\
\hline \multirow{4}{*}{$\mathrm{FC}$} & 5 & 2.94 & 2.91 & 2.82 & 2.49 & 2.49 & 2.73 & & & & \\
\hline & 10 & 2.65 & 2.5 & 2.61 & 2.72 & 2.29 & 2.55 & & & & \\
\hline & 20 & 2.77 & 2.55 & 2.62 & 2.45 & 2.42 & 2.56 & & & & \\
\hline & Mean & 2.79 & 2.65 & 2.68 & 2.55 & 2.4 & - & $0.013 *$ & 0.147 & 0.875 & 13.73 \\
\hline
\end{tabular}

Var: variable; Rac: ractopamine (ppm); NE: net energy; CV: coefficient of variation; FW: finishing weight; DFI: daily feed intake; NEI: net energy intake; DWG: daily weight gain; FC: feed conversion; ${ }^{*} \mathrm{LE}$ : linear effect $(\mathrm{P}<0.05)$; DFI $=4.02127-0.00072 \mathrm{x}$; FC $=4.44195-$ $0.00069707 x$.

provided the nutritional input required for the expression of productive potential. Similar results were obtained by MOURA et al. (2011a) for hot carcass weight and dressing percentage and by PAIANO et al. (2008) for hot carcass weight and yield. QUINIOU \& NOBLET (2012), however, observed higher dressing percentages in barrows for net energy levels of 1,$935 ; 2,078 ; 2,221 ; 2,365$; 2,508; and 2,651 Kcal kg-1.

Net energy levels did not influence either muscle depth or back-fat thickness $(\mathrm{P}>0.05)$. This finding corroborates the results observed for net energy intake, which did not vary across diets, indicating that energy intake was regulated by dietary energy contenti.e., constant energy concentration resulted in uniform quantitative compositions of carcasses. MOURA et al. (2011b) obtained similar results for muscle depth and DE LA LLATA et al. (2001) and REZENDE et al. (2006) for back-fat thickness.

Lean meat percentage was affected $(\mathrm{P}>0.05)$ by net energy levels. These findings are similar to those obtained by REZENDE et al. (2006), PAIANO et al. (2008), and QUINIOU \& NOBLET (2012), demonstrating the ability of pigs to adjust feed intake even in the presence of wide variability in dietary net energy concentrations, resulting in carcasses with consistently similar protein deposition patterns.

Ractopamine levels had no effect $(\mathrm{P}>0.05)$ on carcass characteristics. The literature reports a positive effect of ractopamine on carcass characteristics, particularly in decreasing back-fat thickness; this effect is explained by the ability of this compound to reduce fatty acid synthesis in adipose tissue and to increase protein synthesis in muscle tissue (SANCHES et al., 2010). In the present study, however, ractopamine levels had no effect on back-fat thickness, corroborating results obtained by HINSON et al. (2011).

MOURA et al. (2011a) reported that the effectiveness of ractopamine in reducing lipogenesis in porcine adipose tissue is more pronounced when diets have higher energy content, particularly in the form of lipids. Nonetheless, this response was not observed in the present study-even with the increased net energy levels provided by lipid supplementation, back-fat thickness was unaffected, possibly because net energy consumption remained constant. 
Table 3 - Carcass characteristics of finishing barrows fed diets supplemented with ractopamine.

\begin{tabular}{|c|c|c|c|c|c|c|c|c|c|c|c|}
\hline \multirow{2}{*}{ Var } & \multirow{2}{*}{$\operatorname{Rac}(\mathrm{ppm})$} & \multicolumn{5}{|c|}{$\mathrm{NE}\left(\mathrm{Kcal} \mathrm{kg}^{-1}\right)$} & \multirow{2}{*}{ Mean } & \multicolumn{3}{|c|}{--------------P-value-------------. } & \multirow{2}{*}{ CV $(\%)$} \\
\hline & & 2.300 & 2.425 & 2.550 & 2.675 & 2.800 & & $\mathrm{NE}$ & Rac & Int. & \\
\hline \multirow{5}{*}{$\mathrm{HCW}(\mathrm{kg})$} & 5 & 70.42 & 70.60 & 69.70 & 70.42 & 71.08 & 70.44 & \multirow{5}{*}{0.997} & \multirow{5}{*}{0.062} & \multirow{5}{*}{0.995} & \multirow{5}{*}{6.49} \\
\hline & 10 & 74.30 & 72.56 & 73.64 & 72.34 & 72.70 & 73.25 & & & & \\
\hline & 20 & 70.02 & 71.20 & 69.60 & 71.18 & 69.68 & 70.34 & & & & \\
\hline & Mean & 71.58 & 71.45 & 70.98 & 71.31 & 71.15 & - & & & & \\
\hline & 5 & 76.60 & 74.86 & 73.36 & 78.67 & 70.99 & 74.90 & & & & \\
\hline \multirow{3}{*}{$\mathrm{MD}(\mathrm{mm})$} & 10 & 75.78 & 70.84 & 69.77 & 75.13 & 70.17 & 72.34 & & & & \\
\hline & 20 & 77.31 & 71.09 & 77.05 & 72.57 & 73.43 & 74.29 & \multirow{3}{*}{0.210} & \multirow[b]{2}{*}{0.348} & \multirow[b]{2}{*}{0.757} & \multirow[b]{2}{*}{9.18} \\
\hline & Mean & 76.56 & 72.26 & 73.39 & 75.46 & 71.53 & - & & & & \\
\hline \multirow{4}{*}{ BFT (mm) } & 5 & 12.98 & 11.46 & 11.67 & 14.02 & 12.95 & 12.62 & & \multirow{7}{*}{0.900} & \multirow{7}{*}{0.341} & \multirow{7}{*}{24.16} \\
\hline & 10 & 11.00 & 12.87 & 13.61 & 13.61 & 12.75 & 12.77 & \multirow{6}{*}{0.900} & & & \\
\hline & 20 & 13.32 & 12.44 & 14.32 & 10.47 & 11.35 & 12.38 & & & & \\
\hline & Mean & 12.43 & 12.26 & 13.20 & 12.70 & 12.35 & - & & & & \\
\hline \multirow{4}{*}{ LMP (\%) } & 5 & 60.13 & 60.84 & 60.57 & 59.74 & 59.59 & 60.17 & & & & \\
\hline & 10 & 61.20 & 59.62 & 59.09 & 59.62 & 59.62 & 59.83 & & & & \\
\hline & 20 & 60.01 & 59.89 & 59.4 & 61.18 & 60.76 & 60.25 & & & & \\
\hline & Mean & 60.45 & 60.12 & 59.68 & 60.18 & 59.99 & - & 0.861 & 0.706 & 0.556 & 3.16 \\
\hline
\end{tabular}

Var: variable; Rac: ractopamine; NE: net energy; CV: coefficient of variation; HCW: hot carcass weight; MD: muscle depth; BFT: backfat thickness; LMP: lean meat percentage.

\section{CONCLUSION}

A dietary net energy level of $2,800 \mathrm{Kcal} \mathrm{kg}^{-1}$ is proposed for pigs weighing $70-100 \mathrm{~kg}$, improving feed conversion without affecting carcass characteristics, regardless of dietary ractopamine levels. Ractopamine levels above $5 \mathrm{ppm}$ did not affect performance or modified the quantitative characteristics of carcasses, regardless of dietary net energy levels.

\section{BIOETHICS AND BIOSSECURITY COMMITTEE APPROVAL}

The investigation complied with ethical standards and was approved by the Ethics Committee on Animal Use (permit 429/2012) of the Universidade Federal de Mato Grosso do Sul (UFMS).

\section{ACKNOWLEDGEMENTS}

The authors thanks Coordenação de Aperfeiçoamento de Pessoal de Nível Superior (CAPES) for post-doctoral fellowship the first author.

\section{REFERENCES}

ALMEIDA, V.V. et al. Ractopamine, chromium-methionine and their combinations as metabolism modifier feed additives of growing and finishing pigs. Revista Brasileira de Zootecnia, v.39, p.1969-1977, 2010. Available from: <http://www.scielo. br/pdf/rbz/v39n9/a15v39n9.pdf>. Accessed: Nov. 20, 2013. doi: 10.1590/S1516-35982010000900015.

APPLE, J.K. et al. Effects of dietary lysine and energy density on performance and carcass characteristics of finishing pigs fed ractopamine. Journal of Animal Science, v.82, p.3277-3287, 2004. Available from: <https://www.animalsciencepublications. org/publications/jas/pdfs/82/11/0823277>. Accessed: Jan. 28, 2014. doi: $2004.82113277 x$.

BRIDI, A.M.; SILVA, C.A. Métodos de avaliação da carcaça e da carne suína. Londrina: Midiograf, 2007. 97p.

CORASSA, A. et al. Ractopamine and phytase in diets for finishing pigs. Revista Brasileira de Zootecnia, v.38, p.21742181, 2009. Available from: <http://www.scielo.br/pdf/rbz/ v38n11/a15v3811.pdf $>$. Accessed: Nov. 20, 2013. doi: 10.1590/ S1516-35982009001100015.

DE LA LLATA, M. et al. Effects of dietary fat on growth performance and carcass characteristics of growing-finishing pigs reared in a commercial environment. Journal of Animal Science, v.79, p.2643-2650, 2001. Available from: <http:// www.journalofanimalscience.org/content/79/10/2643.full. pdf + html?sid=f1075de6-f71b-4090-9c3e-564b87624481>. Accessed: Nov. 20, 2013.

HINSON, R.B. et al. Impact of dietary energy level and ractopamine on growth performance, carcass characteristics, and meat quality of finishing pigs. Journal of Animal Science, v.89, p.3572-3579, 2011. Available from: <https://www.animalsciencepublications. org/publications/jas/pdfs/89/11/3572>. Accessed: Jan. 26, 2014. doi: $10.2527 /$ jas.2010-3302. 
KIL, D.Y. et al. Net energy of soybean oil and choice white grease in diets fed to growing and finishing pigs. Journal of Animal Science, v.89, p.448-459, 2011. Available from: <http://www. journalofanimalscience.org/content/89/2/448.long $>$. Accessed: Nov. 20, 2013. doi: 10.2527/jas.2010-3233.

MOURA, M.S. et al. Net energy and ractopamine to finishing gilts under high temperature environment. Ciência Rural, v.41, p.888894, 2011a. Available from: <http://www.scielo.br/pdf/cr/v41n5/ a964cr4196.pdf $>$. Accessed: Nov. 20, 2013. doi: 10.1590/S010384782011000500025 .

MOURA, M.S. et al. Net energy and ractopamine levels for finishing gilts under thermal comfort. Revista Brasileira de Zootecnia, v.40, p.1968-1974, 2011b. Available from: <http:// www.scielo.br/pdf/rbz/v40n9/a18v40n9.pdf>. Accessed: Nov. 20, 2013. doi: 10.1590/S1516-35982011000900018.

PAIANO, D. et al. Digestible threonine: lysine ratios and net energy levels in growing/finishing pigs. Revista Brasileira de Zootecnia, v.37, p.2147-2156, 2008. Available from: $<$ http://www. scielo.br/pdf/rbz/v37n12/11.pdf $>$. Accessed: Nov. 08, 2013. doi: 10.1590/S1516-35982008001200011.

QUINIOU, N.; NOBLET, J. Effect of the dietary net energy concentration on feed intake and performance of growing-finishing pigs housed individually. Journal of Animal Science, v.90, p.43624372, 2012. Available from: <http://www.journalofanimalscience. org/content/90/12/4362.full.pdf+html>. Accessed: Nov. 08, 2013. doi: $10.2527 /$ jas.2011-4004.

REZENDE, W.O. et al. Metabolizable energy levels maintaining digestible lysine: calorie ratio in diets for finishing barrows. Revista Brasileira de Zootecnia, v.35, p.1101-1106, 2006. Available from: $<$ http://www.scielo.br/pdf/rbz/v35n3s0/30723.pdf $>$. Accessed: Nov. 08, 2013. doi: 10.1590/S1516-35982006000400022.

ROSTAGNO, H.S. et al. Tabelas brasileiras para aves e suínos: composição de alimentos e exigências nutricionais. 3.ed. Viçosa: UFV, 2011. 252p.

SANCHES, J.F. et al. Ractopamine levels for finishing barrows maintained in heat stress. Revista Brasileira de Zootecnia, v.39, p.1523-1529, 2010. Available from: <http://www.scielo.br/pdf/ rbz/v39n7/a19v39n7.pdf $>$. Accessed: Oct. 10, 2013. doi: 10.1590/ S1516-35982010000700019.

YI, X.W. et al. Influence of dietary net energy content on performance of growing pigs fed low crude protein diets supplemented with crystalline amino acids. Journal of Swine Health and Production, v.18, p.294-300, 2010. Available from: <http://www.aasv.org/shap/ issues/v18n6/v18n6p294.pdf>. Accessed: Nov. 08, 2013. 